\title{
Travelers In The Mediterranean: The Case For Ancient Parians
}

Dora Katsonopoulou ${ }^{1}$

\section{ABSTRACT}

The island of Paros located in the centre of the Aegean Sea, emerged as an organized polis/state already in mid-8th century BC. Its geographical position favored early sea communications and foundation of colonies along the Mediterranean. In the article, I discuss the impressive phenomenon of itinerant Parians in the Mediterranean in relation to (a) the colonies founded by Paros in the Propontis, the North Aegean and the Adriatic Sea, (b) certain activities of travelling groups of artists in Greece proper and the periphery of the Greek world, and (c) two exceptional cases of itinerant Parians, Archilochos the poet (7th century BC) and Skopas the sculptor and architect (4th century BC). Finally, a short mention is made of another type of mobilization of fighters, under state control.

KEYWORDS

Ancient Paros, Mediterranean Sea, itinerant artists, Aegean world, Adriatic Sea.

\footnotetext{
${ }^{1}$ The Institute for Archaeology of Paros and the Cyclades, Paros, Greece. Email: paros.iapk@gmail.com.
} 
The island of Paros lies almost in the centre of the insular complex of the Cyclades (Fig. 1) which connects the Aegean Sea with the Greek mainland and the Near East. Before the 2nd millennium BC Paros was a much larger island (The Greater Paros) together with the islands of Antiparos, Despotiko and other uninhabited islets, and was connected with the island of Naxos via a narrow strip of land. When physically separated from Antiparos sometime in the 2nd millennium BC, Paros continued to keep under its control the entire group of islands until at least the Hellenistic times. The geographical position of the island in the centre of the Cyclades, the favorable landscape and mild climate favored its early habitation and the maritime communications within and beyond the Aegean.

Paros seems to have hosted settlements since the end of the 4th millennium BC. In the beginning of the 2 nd millennium BC, a significant settlement developed in the area of the modern Paros capital, and another important Mycenaean settlement flourished on the summit of the hill of Koukounaries in the bay of Naousa in northern Paros (Schilardi 2016). Numerous settlements prospered during the Geometric period and by mid-8th century BC Paros had emerged as an organized polis/state of significant power (Zapheiropoulou 2008). In the following Archaic period, the island reached its peak and became a most significant economic and cultural center in the Aegean. Among the activities developed, contacts and exchanges, trade and shipping became predominant. Especially, the trade of the superb white Parian marble, the most sought after marble in the ancient world, proved particularly profitable for Parian economy during the Archaic and the Early Classical periods. Literary and archaeological evidence show that its use for statuary and embellishment of public buildings was in demand until well into the Roman times and spread to numerous places, thus connecting Paros with a wide network of clients in the Aegean and the Mediterranean worlds.

Let us now take a closer look at these islanders and their multiple activities. Already in early historical times, the Parians ventured travels abroad in groups or individually. Before the end of the century, Paros founded its first colony in the Southern Black Sea, Parion (ca. 709 BC), most probably in a joint enterprise with the cities of Miletos and Erythrai (Keles 2018, p. 179). The name of the mother island, Paros, is among the names mentioned in connection with the name of the colony itself, the other two being those of Parios of Erythrai or Alexander Paris - the famous prince of Troy (Keles 2018, p. 179). The Trojan hero was a very important figure for the city of Parion and its past history. 
His tomb is said to have been located in the Agora of the city, where also stood his bronze statue by the famous Greek sculptor Euphranor of the 4th century BC from the Isthmos near Corinth. However, the particular ties of Parion with Paros may be indicated by the dedication of another famous work in Parion, the bronze statue of Herakles made by the early 5th century BC sculptor Hegesias of Athens (Katsonopoulou 2020, pp. 495-497). Given Herakles' reported association with colonial activities of Paros and the close connections of his life with both regions, Paros and the Troad, his statue in this case may allude to this capacity of the hero. Parion, located on an important route connecting the Black Sea with the Aegean Sea via the Hellespont, emerged as a significant trading post and a site of strategic importance for the region.

The foundation, only a few decades later, of another colony in the Northern Aegean shows the constant interest of the island of Paros in expanding its commercial and economic activities in the Northern Aegean - Black Sea line of trade routes. Beginning with the exploitation of resources available in the colonies, especially in Thasos of the agricultural and mineral wealth, and establishing good relationships via strong cultural and religious ties, the metropolis apparently increased its power and influence in a much wider area, economically and culturally.

The Parian settlement in the island of Thasos, established ca. 680 BC under Telesikles, the father of the famous poet of Paros Archilochos, was reinforced by a second wave of colonists ca. $650 \mathrm{BC}$, including the poet himself who served both as a settler and a soldier. In the surviving excerpts of his poetry, Archilochos recounts the life he lived in the colony, serving in the army alongside the general Glaukos, head of the army during the second generation of Parian settlers (Clay 2004). The famous poem of tossing away his shield to save his life when pursued by the Thracian enemy (Fr. $5 \mathrm{~W}$ ), is among the most shocking ones shedding light to the retreat in battles, an entirely untold aspect of a warrior's life before him (Katsonopoulou 2008). As Archilochos himself declares in Fr. $1 \mathrm{~W}$, he possessed the lovely gift of Muses, serving by telling the truth to others, as much as he was the servant of Enyalios, the god of war.

In another Fr. 22, quoted by Athenaios (Deipn. 12.25), Archilochos describes his admiration for the region of Siris that is beautiful, charming and desirable, with running waters, as opposed to the inhospitable landscape of the island of Thasos. The reference to yet another land beyond Thasos, further supports Archilochos' supposed mercenary status as a soldier, Siris identified in this case with the river in South Italy and the homonymous 
city situated at the river's mouth (Tsantsanoglou 2008, p. 177). According to other views, the comparison made in Fr. 22 concerns the neighbouring valley of the Strymon river, in the mainland opposite Thasos, where also a town by the same name was located (Jacobs 1798, p. 166; Grandjean and Salviat 2012, p. 39). However, recent archaeological evidence from South Italy seems to support the identification of Siris mentioned in Archilochos with the region of Italian Siris. The study of archaeological finds from the excavations of Siris and especially of Archaic pottery excavated from the site of Incoronata indicate the presence of Parian potters and painters in the region, in Archilochos' time. Comparison of technical, stylistic and iconographic elements between Incoronata and the Cyclades suggest that the Cycladic potters, active at the site during the 7th century BC, came from Parian and Naxian Schools (Denti 2018, pp. 49-52). Their presence and activity in South Italy sheds light to a much broader phenomenon of travelling Parians in the Mediterranean diffusing Parian art and culture far away from their home island.

Part of this same phenomenon is also the attested presence of Parian sculptors in Sicily and South Italy, two significant cultural areas of Western Mediterranean, in the Archaic and Early Classical periods. The Western Greek poleis embellished their sanctuaries and public spaces with Parian marble sculptures. The use of the Parian marble was extensive and included also marble roofs. Recent evidence, especially from Akragas (Adornato 2021) and Selinous (Marconi 2021), show that Parian marble imports travelled to the West and with them Parian craftsmen who worked in their new destinations either to finish partly carved sculptures that travelled from Paros, or to carve in situ new statues out of the shipped marble blocks. Passing down their artistic knowledge and technology in the new areas, where they settled and worked, these groups of artists acted as agents of growing influence on behalf of their homeland in the periphery of the Greek world and contributed to establishing a sort of international relationships between Paros and the West.

The interest of Paros in the West indicated already in the Archaic and Early Classical periods, was again revived in the 4th century BC, when the island founded a new colony in the Adriatic Sea, more than 300 hundred years later than its earliest colonies of Parion in the Propontis and Thasos in the Northern Aegean. The position of the new colony, named Pharos, in a proper location in the Adriatic could well serve Paros' interests in commercial and economic activities in the region. A review of the 
archaeological data from the site of Pharos (Kirigin 2006) suggests a well organized and export-oriented Parian settlement. The close relations with the metropolis are reflected in Pharos' coinage adopting the Parian emblem of the goat on the reverse of its coins since its beginnings in the 4th century BC (Kirigin 2003, pp. 26-28). It is of particular interest that following Pharos' foundation in Dalmatia in 385/4 BC, a new period of prosperity is observed in the island of Paros. New buildings and temples were constructed including the Prytaneion of the city with the temple and the cult statue of Hestia, a work of the renowned sculptor of the 4th century BC Skopas of Paros (Gruben 1999; Katsonopoulou 2004). Such a flourishing was probably related with the profit directed to the metropolis via trading activities of its colony in the Adriatic (Katsonopoulou 2021). The income from exporting wine alone was almost enormous according to archaeological evidence from Pharos (Kirigin 2018).

Apparently, the Parian colonies located in proper positions along the Mediterranean from East to West, contributed to a great extent in the enhancement of the status of their metropolis Paros. However, strong cultural influence of Paros in the Greek world seems to have been exercised also via certain individuals distinguished in the fields of Letters and Arts. Although we are aware of many such examples of prominent Parians from the Archaic and Classical times, I will limit myself here to two exceptional cases, Archilochos the poet and Skopas the sculptor and architect (Katsonopoulou 2019).

Archilochos and his revolutionary poetry reached far outside the island of Paros. In the Greek world, the Parian poet was held worthy of comparison only to Homer. He himself and his invective poetry were often the subject of discussion by critics, philosophers, grammarians and epigrammatists and many studies were written about the poet and his extraordinary work. Immortal and renowned in song, according to the Delphic oracle announced to his father Telesikles, Archilochos made his island immortal too. Interacting with Greeks and non-Greeks in so many different parts of the ancient world, where he travelled, as suggested from the surviving fragments of his poetry, he was apparently part of a network connecting Paros with other regions of the world.

In the same path followed three centuries later another great Parian, Skopas the sculptor and architect, one of the most itinerant Greek artists. Like Archilochos, Skopas travelled a lot outside the island creating exceptional sculptures and architectural works in numerous places of the ancient world, from the Peloponnese in the mainland to Attica, to Central Greece, to the North and to the East from Troad to Ionia. Skopas was the 
introducer in the art of sculpture of the unique style of pathos, expressing through his figures the inner passionate feelings of their soul, in contrast to the serene and harmonious Classical figures of the previous 5th century. His style greatly influenced contemporary and later sculptural art. Skopas and Archilochos share the same feature of expressing in their pioneer works personal experience as opposed to the heroic element of the past (Katsonopoulou 2019). Archilochos remained a favourite subject among ancient scholars as late as Roman times. And Skopas was the most highly regarded Greek sculptor in imperial Rome, where many of his works were present. His timeless value and fame made famous Paros itself as indicated by the epithet Parios (Пó in ancient sources.

Finally, a short mention should be made to another type of travelling involving fighters to fight a battle away from home. The most characteristic such case from Paros concerns the two polyandria (multiple burials) discovered in the main ancient cemetery of the city of Paros in modern Paroikia. The polyandria, dated between the third quarter of the 8th and the early years of the 7th century BC (Zafeiropoulou 1994, 1999), contained 160 amphorae holding the burnt bones of dead warriors suggesting the ability of the state to mobilize a large force of fighters to fight a battle outside the island. Their burial back in Paros in the main cemetery of the polis, and the demarcation of the area of their interment by the erection of a marble stele representing an enthroned female figure dated to ca. 700 BC (Mavragani 2000), indicate that this was a communal action. Similarly, Archilochos' mention of a group of a thousand men with reference to the second mission to Thasos (Fr. 97W) shows mobilization of major groups of citizens most probably under state control.

\section{Conclusion}

From the above presented paradigms of travelling Parians, it becomes evident that Paros makes an exceptional case of a cosmopolitan island of the Aegean, which maintained communication and contacts with many other regions in the Aegean Sea and the coast of Asia Minor since early historical times. Recent archaeological evidence shows that relations and contacts were developed also with the West since the Archaic period. In the framework of their interests, especially in trade and shipping, the Parians were active in the Aegean and the Mediterranean for many centuries, thus contributing in the enhancement of the island's economy and culture. These aims were well served 
through (a) the foundation of a number of colonies extending from the Southern Black Sea and the Northern Aegean to the Adriatic Sea, (b) the export and diffusion of the Parian marble in numerous places of the ancient world, and (c) the great works of its itinerant intellectuals and artists. Another reason for travelling seems to have been the mobilization of citizens, under state control, as fighters away from home.

Article received in: 01/11/2021

Approved in: 01/12/2021 
Mare Nostrum, ano 2021, v. 12, n. 2

\section{Figure}

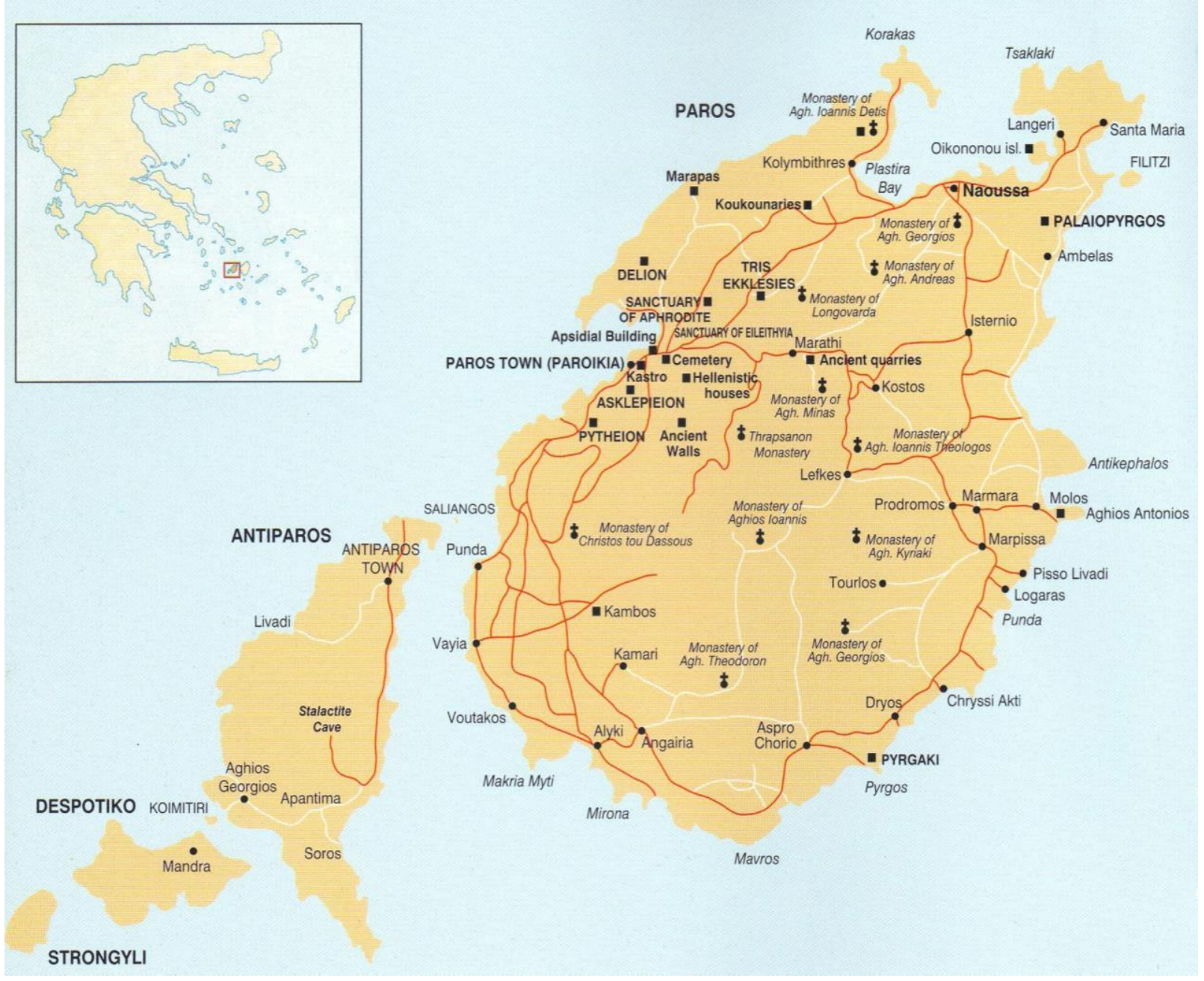

Figure 1: Map of Paros and surrounding islands (from Kourayos 2004, p. 8). 


\section{BIBLIOGRAPHIC REFERENCES}

Adornato, G. (2021). Parian Marble Sculpture at Akragas: Workshops and Legacy. In D. Katsonopoulou (Ed.) Paros V, Paros through the Ages - From Prehistoric Times to the 16th Century AD (pp. 145-160). The Institute for Archaeology of Paros and the Cyclades, Athens.

Clay, Diskin (2004). Archilochos Heros - The cult of Poets in the Greek Polis. Harvard University Press, Cambridge.

Denti, M. (2018). Archilochos did not Sail Alone to the Bountiful Shores of Siris: Parian and Naxian Potters in Southern Italy in the 7th Century BC. In D. Katsonopoulou (Ed.) ParosIV, Paros and its Colonies (pp. 39-63). The Institute for Archaeology of Paros and the Cyclades, Athens.

Grandjean, Y. \& Salviat, F. (2012). Guide de Thasos (in Greek). Ecole Francaise d' Athenes, Athens.

Gruben, G. 1999. Wandernde Saulen auf Naxos. In N. Stampolides (Ed.) Fos Kykladikon (pp. 296-317). N. Goulandris Foundation, Athens.

Jacobs, F. (1798). Animadversiones in Epigrammata Anthologiae Graecae. Leipzig.

Katsonopoulou, D. (2004). Skopas and Paros. NAC, 36, 157-168.

Katsonopoulou, D. (2008). Telephos Arkasides in a New Poem of Archilochos. In D. Katsonopoulou, I. Petropoulos, \& S. Katsarou (Eds.) Paros II, Archilochos and his Age (pp. 289-301). The Institute for Archaeology of Paros and the Cyclades, Athens.

Katsonopoulou, D. (2019). On the Legacy of two Exceptional Parians: Archilochos the Poet and Skopas the Sculptor. NAC, 48, 23-31.

Katsonopoulou, D. (2020). Famous Sculptures by Classical Greek Masters in Parion and the Troad. In V. Keles (Ed.) Propontis and Surrounding Cultures (pp. 495-502). Ege Yayinlari, Istanbul.

Katsonopoulou, D. (2021). Paros in the Fourth Century BC and the Foundation of Pharos. VAHD, 113, 109-118, Split.

Keles, V. (2018). Some Observations on the Altar of Hermokreon in Parion. In D. Katsonopoulou (Ed.) Paros IV, Paros and its Colonies (pp. 179-187). The Institute for Archaeology of Paros and the Cyclades, Athens.

Kirigin, B. (2003). Pharos. An Archaeological Guide, Stari Grad. 
Kirigin, B. (2006). PHAROS. The Parian Settlement in Dalmatia. BAR International Series 1561, Oxford.

Kirigin, B. (2018). Pharos, Greek Amphorae and Wine Production. In D. Katsonopoulou (Ed.) ParosIV, Paros and its Colonies (pp. 397-419). The Institute for Archaeology of Paros and the Cyclades, Athens.

Marconi, C. (2021). The Case for Parian Sculptors in Selinous and Western Sicily in the Early Classical Period. In D. Katsonopoulou (Ed.) Paros V, Paros through the Ages - From Prehistoric Times to the 16th Century AD (pp. 119-144). The Institute for Archaeology of Paros and the Cyclades, Athens.

Mavragani, K. (2000). Observations on the Earliest Funerary Stele (No 760) of the Museum of Paros. In D. U. Schilardi \& D. Katsonopoulou (Eds.) Paria L;ithos (pp. 155-161). The Institute for Archaeology of Paros and the Cyclades, Athens.

Schilardi, D. (2016). Koukounaries Paros. The Excavations and History of a Most Ancient Aegean Acropolis. Athens.

Tsantsanoglou, K. (2008). Archilochos Fighting in Thasos: Frr. 93a and 94 from the Sosthenes Inscription. In D. Katsonopoulou, I. Petropoulos, \& S. Katsarou (Eds.) Paros II, Archilochos and his Age (pp. 163-180). The Institute for Archaeology of Paros and the Cyclades, Athens.

Zafeiropoulou, Ph. (1994). Une nécropole á Paros. In Nécropoles et sociétés antiques (pp. 127-152). Cahiers du Centre Jean Berard XVIII, Naples.

Zafeiropoulou, Ph. (1999). I due "Polyandria" dell' antica necropolis di Paros. Annali di archeologia e storica antica, 13-16.

Zafeiropoulou, Ph. (2018). Paros: A Flourished City from the $8^{\text {th }}$ Century BC to Late Antiquity (in Greek). In D. Katsonopoulou (Ed.) ParosIV, Paros and its Colonies (pp. 65-76). The Institute for Archaeology of Paros and the Cyclades, Athens. 


\section{Viajantes No Mediterraneo: O Caso dos Antigos Parios}

Dora Katsonopoulou

\section{RESUMO}

A ilha de Paros, localizada no centro do Mar Egeu, surgiu como uma polis/Estado organizado já em meados do século VIII a.C. Sua posição geográfica favoreceu as primeiras comunicações marítimas e a fundação de colônias no Mediterrâneo. No artigo, discuto o impressionante fenômeno dos pários itinerantes no Mediterrâneo em relação (a) às colônias fundadas por Paros na Propôntida, no Egeu do Norte e no Mar Adriático, (b) certas atividades de grupos itinerantes de artistas na Grécia propriamente dita e na periferia do mundo grego, e (c) dois casos excepcionais de pários itinerantes - Arquílocos, o poeta (século VII a.C.), e Skopas, o escultor e arquiteto (século IV a.C.). Finalmente, uma breve menção é feita sobre outro tipo de mobilização de combatentes, sob controle estatal.

PALAVRAS-CHAVE

Paros antiga, Mar Mediterrâneo, Artistas itinerantes; Mundo egeu; Mar Adriático. 